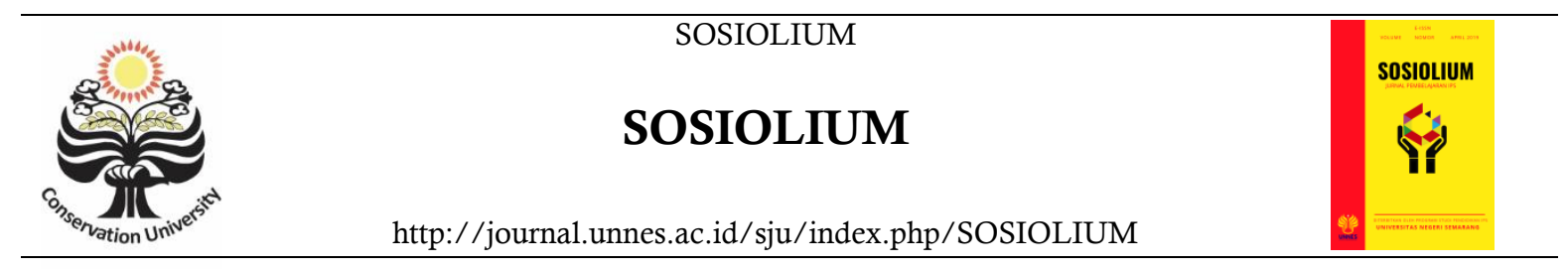

\title{
ANALISIS KENDALA PERENCANAAN BELAJAR TUNTAS DITENGAH PANDEMI COVID-19 OLEH GURU IPS KECAMATAN KARANGPUCUNG KABUPATEN CILACAP
}

\author{
Mellania Nur Mahmudah, Ferani Mulianingsih ${ }^{凶}$ \\ Prodi Pendidikan Ilmu Pengetahuan Sosial, Fakultas Ilmu Sosial, Universitas Negeri Semarang, Indonesia
}

\begin{tabular}{l}
\hline Info Artikel \\
\hline Sejarah Artikel: \\
Disubmit: Juli 2021 \\
Direvisi: Agustus 2021 \\
Diterima: September \\
2021 \\
\hline
\end{tabular}

\section{Keywords:}

IPS (Social science) Teacher;

Covid-19 Pandemic;

Mastery Learning

\begin{abstract}
Abstrak
Penelitian ini bertujuan untuk menganalisis faktor kendala penerapan pembelajaran tuntas ditengah pandemi covid-19 bagi guru mata pelajaran IPS Kecamatan Karangpucung Kabupaten Cilacap. Penelitian ini merupakan penelitian kualitatif yaitu penelitian yang berlandaskan pada filosofi positivism dan mengetahui bagaimana penerapan pembelajaran tuntas dibeberapa SMP/MTS Kecamatan Karangpucung Kabupaten Cilacap. SMP/MTS tersebut meliputi SMP N 1 Karangpucung, SMP Islam Karangpucung dan MTS Nurul Huda Karangpucung. Langkah-langkah penelitian meliputi faktor internal perencanaan pembelajaran tuntas dan upaya untuk mengatasi kendala tersebut. Dari hasil penelitian guru IPS dalam penerapan pembelajaran ditengah pandemi covid-19, kendala tersebut antara lain tidak memiliki alat pembelajaran atau smartphone, kuota internet yang sangat terbatas, jaringan internet yang tidak stabil, kurangnya pemahaman materi, kurangnya motivasi belajar pada peserta didik dan peserta didik mengalami kesulitan dalam belajar.
\end{abstract}

\begin{abstract}
This study aims to analyze the safety factor of the application of complete learning in the midst of the Covid-19 pandemic for social studies subject teachers, Karangpucung District, Cilacap Regency This research is a qualitative research that is research based on the philosophy of positivism and finding out how to apply complete learning in several SMP / MTS, Karangpucung District, Cilacap Regency. The SMP / MTS includes SMP N 1 Karangpucung, SMP Islam Karangpucung and MTS Nurul Huda Karangpucung. The research steps included internal factors of complete learning planning. From the results of research that is too strict which is protected by social studies teachers in the application of learning amid the Covid-19 pandemic. These constraints include not having a learning tool or smartphone, a very limited quota, an unstable internet network, a lack of understanding of the material and a lack of student motivation. Communication constraints that are communicated by social studies teachers are the smallest part of students, who have the most difficulty in learning students.
\end{abstract}

E-mail: feranigeographer@mail.unnes.ac.id 


\section{PENDAHULUAN}

Belajar tuntas merupakan salah satu prinsip dari kurikulum berbasis kompetensi, termasuk kurikulum 2006 (KTSP) dan kurikulum 2013. Prinsip ini mengisyaratkan bahwa peserta didik harus mencapai ketuntasan dalam belajarnya. Tidak saja tuntas materi namun secara keseluruhan harus tuntas dalam menguasai kompetensi yang telah ditetapkan. Kemendiknas No $41 \quad(2007: 11)$ dan Kemendikbud No 22 (2016:7) menetapkan bahwa dalam proses pembelajaran menjadikan kurikulum satuan pendidikan (KTSP) dan Kurikulum 2013 menggunakan sistem pembelajaran berbasis komputer, sistem belajar tuntas dan sistem pembelajaran yang memperhatikan masing-masing perbedaan individu. Pendekatan belajar tuntas harus bisa dilaksanakan secara sistematis agar peserta didik memperoleh hasil yang maksimal terhadap seluruh materi yang dipelajari. Kesistemaisan akan tercermin dari strategi pembelajaran yang dilaksanakan, terutama dalam mengorganisisr tujuan dan bahan ajar, melaksanakan evaluasi dan memberikan bimbingan terhadap peserta didik yang gagal mencapai tujuan yang ditetapkan (Amri,2010:196).

Proses pembelajaran disekolah merupakan alat kebijakan publik terbaik sebagai upaya peningkatan pengetahuan dan skill. Selain itu banyak peserta didik menganggap bahwa sekolah adalah kegiatan yang sangat menyenangkan. Sekolah secara keseluruhan adalah media interaksi antar peserta didik dan guru untuk meningkatkan kemampuan integensi, skill dan rasa kasih saying diantara mereka. Tetapi sekarang kegiatan pembelajaran disekolah dihentikan dengan tiba-tiba karena adanya pandemi covid-19. Pelaksanaan pembelajaran berlangsung secara online. Penilaian peserta didik dilaksanakan secara online dan banyak train and error dengan sistem yang tidak ada kepastian. Dampak pendidikan dari sisi waktu jangka panang adalah aspek keadilan dan peningkatan ketidaksetaraan antar kelompok masyarakat dan antar sekolah di Indonesia.

Kurikulum adalah seperangkat rencana dan pengaturan mengenai tujuan, isi dan bahan pelajaran serta cara yang digunakan sebagai pedoman penyelenggaraan kegiatan pembelajaran untuk mencapai tujuan pendidikan tertentu. Pemerintah menyiapkan dukungan kebijakan pelaksanaan kurikulum dimasa khusus, yakni satuan pendidikan dapat 1) Tetap menggunakan kurikulum nasional, 2) Menggunakan penyederhanaan kurikulum dalam kondisi khusus yang disusun oleh Kemendikbud, dan 3) Melakukan penyederhanaan kurikulum secara mandiri. Kementrian pendidikan dan Kebudayaan (Kemendikbud) menerbitkan Keputusan Mentri Pendidikan dan Kebudayaan Republik Indonesia Nomor 719/P/2020 tentang Pedoman Pelaksanaan Kurikulum pada Satuan Pendidikan dalam kondisi khusus dapat menggunakan kurikulum sesuai dengan kebutuhan pembelajaran peserta didik. Berdasarkan fakta dilapangan, masih ditemukan problematika guru IPS terkait dengan penerapan pembelajaran tuntas ditengah pandemic covid-19. Problematika yang dialami guru IPS yaitu diantaranya partisipasi peserta didik belum maksimal dalam pembelajaran ditengah pandemik covid-19 hal ini dikarenakan karena adanya beberapa kendala yang dihadapi oleh peserta didik. Untuk menghadapi hambatan tersebut, diperlukan kesiapan pendidik, kurikulum yang sesuai dengan kondisi sekolah dan peserta didik, ketersediaan sumber belajar yang memadai, serta peranti dan jaringan yang stabil sehingga komunikasi antara guru dan peserta didik berjalan efektif. Kondisi pelaksanaan belajar tuntas pada pembelajaran ditengah pandemic covid-19 belum dapat disebut ideal sebab sebab masih terdapat berbagai hambatan yang dihadapi. Hasil observasi awal menunjukan bahwa hambatan yang dihadapi oleh Guru IPS di Kecamatan Karangpucung Kabupaten Cilacap dalam pelaksanaan pembelajaran tuntas berkaitan dengan kesiapan sumber daya manusia mleiputi pendidik, peserta didik dan orangtua peserta didik. Selanjutnya masih kurang jelasnya arahan dari pemerintah daerah setempat, belum adanya kurikulum yang tepat sesuai kondisi sekolah dan peserta didik, dan keterbatasan sarana prasarana khususnya jaringan internet dan dukungan teknologi. Terkait hal tersebut, penerapan pelaksanaan pembelajaran tuntas ditengah pandemic covid-19 tidak berjalan dengan semestinya. Guru IPS di Kecamatan Karangpucung mengalami kesulitan dalam melakukan pendekatan terhadap peserta didik dan mengalami kesulitan dalam penilaian peserta didik karena pembelajaran tidak 
berlangsung dengan cara tatap muka. Berdasarkan latarbelakang tersebut peneliti berfokus mengetahui analisis faktor kendala dalam perencanaan pembelajaran tuntas ditengah pandemi covid-19 oleh guru mata pelajaran IPS Kecamatan Karangpucung Kabupaten Cilacap.

\section{METODE}

Penelitian ini merupakan penelitian kualitatif, yaitu penelitian yang berlandaskan pada positivism. Digunakan untuk meneliti pada obyek yang alamiah, dimana peneliti adalah instrument kunci, teknik pengumpulan data dilakukan secara triangulasi (gabungan), analisis data bersifat induktif/kualitatif lebih menekankan makna daripada generaliasasi. Lokasi penelitian dilakukan pada tiga sekolah menengah pertama di Kecamatan Karangpucung Kabupaten Cilacap yaitu SMP N 1 Karangpucung, SMP Islam Karangpucung dan MTS Nurul Huda Karangpucung.

Fokus dalam penelitian ini yaitu mengenai faktor kendala dalam perencanaan belajar tuntas ditengah pandemi covid-19 oleh guru mata pelajaran IPS Kecamatan Karangpucung Kabupaten Cilacap dan upaya yang dilakukan oleh sekolah untuk mengatasi kendala tersebut. Karangpucung Kabupaten Cilacap. Sumber data penelitian dibedakan menjadi 2 yaitu sumber data primer dan sumber data sekunder (Sugiyono, 2017:308). Data primer dalam penelitian ini diperoleh dari hasil observasi dan wawancara pada guru IPS, Kepala Sekolah, beberapa peserta didik dan Ketua MGMP IPS Kabupaten Cilacap. Sedangkan data sekunder meliputi buku-buku, arsip sekolah, dokumentasi dari berbagai pihak, dan literatur yang berkaitan dengan tujuan penelitian yang telah ditentukan oleh peneliti. Teknik pengumpulan data dilakukan dengan cara observasi, wawancara dan dokumentasi. Wawancara dilakukan secara langsung (mematuhi protokol kesehatan) dengan informan utama yaitu guru IPS, kemudian dengan informa pendukung yaitu Kepala sekolah dan peserta didik. Untuk informan pendukung Ketua MGMP IPS wawancara dilakukan melalui zoom meeting berdasarkan kesepakatan bersama karena adanya pandemi covid-19. Moleong (2011:330) menjelaskan bahwa keabsahan data dalam penelitian kualitatif dapat diperoleh melalui triangulasi.
Triangulasi yang digunakan dalam penelitian yaitu triangulasi sumber. Teknik analisis data dalam penelitian ini meliputi reduksi data, penyajian data dan verifikasi atau penyimpulan data.

\section{HASIL PENELITIAN}

Kabupaten Cilacap adalah salah atu kabupaen di Provinsi Jawa Tengah dengan luas 238.500 Ha. Lokasi penelitian berada pada salah satu kecamatan di Kabupaten Cilacap yaitu Kecamatan Karangpucung. Penelitian dilaksanakan di Kecamatan Karangpucung tepatnya ditiga sekolah yaitu SMP N 1 Karangpucung, SMP Islam Karangpucung dan MTS Nurul Huda Karangpucung.

\section{Faktor Kendala Perencanaan Pembelajaran Tuntas ditengah Pandmei Covid-19 Oleh Guru Mata Pelajaran IPS Kecamatan Karangpucung Kabupaten Cilacap}

Sebelum kegiatan pembelajaran dimulai, Kepala SMP N 1 Karangpucung, Kepala SMP Islam Karangpucung dan Kepala MTS Nurul Huda Karangpucung sudah memberikan arahan kepada guru IPS untuk membuat perencanaan penerapan pembelajaran tuntas. Bentuk tertulis dari perencanaan tersebut yaitu silabus dan RPP yang sudah dibuat oleh guru mata pelajaran IPS Kecamatan Karangpucung Kabupaten Cilacap. Perencanaan yang telah dibuat merupakan antisipasi atau perkiraan tentang apa yang dilakukan dalam pengajaran sehingga tercipta situasi yang memungkinkan terjadi dalam proses pembelajaran ditengah pandemic covid-19 baik itu pembelajaran dengan cara daring atau pembelajaran dengan cara luring yang dapat mengantarkan peserta diik kepada tujuan yang telah diharapkan. Hal penting dalam perencanaan pembelajaran tuntas ditengah pandemic covid-19 yaitu memperhatikan kurikulum yang digunakan dimasing-masing sekolah. Berdasarkan hasil penelitian, penerapan kurikulum di SMP 1 Karangpucung tetap menggunakan kurikulum 2013 dan terdapt penyederhanaan disetiap jam pelajarannya. Penerapan kurikulum di SMP Islam Karangpucung menggunakan kurikulum darurat yang sudah dirancang oleh pemerintah ditengah pandemic covid-19. Penerapan kurikulum di MTS Nurul Huda Karangpucung menggunakan 2 kurikulum yaitu kurikulum 2013 dan kurikulum darurat ditengah pandemic covid-19.

Hal-hal yang harus diperhatikan dalam perencanaan pembelajaran tuntas ditengah pandemic covid-19 di SMP N 1 Karangpucung, 
SMP Islam Karangpucung dan MTS Nurul Huda Karangpucung yaitu yang pertama prasyarat sebelum pembelajara. Untuk mempersiapkan pelaksanaan pembelajaran tuntas, guru IPS menentukan prasyarat untuk mencapai tujuan pembelajaran. Salah satu prasyarat untuk pembelajaran tuntas adala berkembang terutama materi yang harus dikuasai oleh peserta didik. Prasyarat kedua adalah tujuan itu harus dinyatakan dalam alat penilaian agrerat untuk bisa seperti yang kita ketahui bersama tingkat keberhasilan peserta didik. Strandar yang harus dikuasai oleh peserta didik dalam pembelajaran tuntas ditengah pandemic covid-19 oleh guru mata pelajaran IPS SMP N 1 Karangpucung, SMP Islam Karangpucung dan MTS Nurul Huda Karangpucung yaitu menggunakan tes tertulis, tes lisan, tugas yang sudah diberikan oleh guru mata pelajaran IPS dan keaktifan peserta didik ketika sedang melaksanakan kegiatan pembelajaran menggunakan media daring seperti google classroom dan whatssapp.

Yang kedua yaitu dasra perencanaan pembelajaran tuntas ditengah pandemi covid19. Hal penting lain yang harus diperhatikan dalam perencanaan pembelajaran ditengah pandemi covid-19 yaitu sebelum mengajar guru harus merencanakan strategi dan membuat suatu perencanaan pembelajaran yang efektif dan efesien ditengah pandemic covid-19. Berdasarkan hasil penelitian, bahwa guru mata pelajaran IPS SMP N 1 Karangpucung, SMP Islam Karangpucung dan MTS Nurul Huda Karangpucung menentukan dasar perencanaan pembelajaran tuntas. Namun setiap guru memiliki cara tersendiri untuk merencanakan pembelajaran tuntas ditengah pandemi covid19. Tetapi dari beberapa guru masih ada yang belum memahami tentang perencanaan pembelajaran tuntas yang harus dibuat oleh guru mata pelajaran IPS. Dalam perencanaan pembelajaran tuntas guru IPS harus memperhatikan beberapa aspek penting yaitu penetapan KKM dan diagnostik kesulitan belajar pada peserta didik. Sebelum melakukan pembelajaran, guru mata pelajaran IPS wajib mementukan diagnostik kesulitan pada peserta didik dan penetapan KKM sesuai dengan kemampuan peserta didik dan kondisi sekolah. Berdasarkan hasil penelitian, peneliti telah menyimpulkan bahwa 4 guru IPS menentukan KKM dengan cara memperhatikan kemampuan peserta didik dan kondisi peserta didik ditengah pandemi covid-19. Dan 3 guru IPS menentukan KKM dengan cara mengacu pada kurikulum 2013 dan kondisi pandemi covid-19. Walaupun begitu, setiap guru memiliki kriteria tertentu dalam penetapan KKM ditengah pandemi covid-19. Tentunya dengan cara tetap mengacu kepada kurikulum yang sudah ditetapkan, kemampuan peserta didik dan memperhatikan kondisi ditengah pandemic covid-19.

Yang ketiga yaitu tujuan pembelajaran. Berdasarkan hasil penelitian yang telah dilakukan, bahwa tujuan pelaksanaan pembelajaran yaitu agar pembelajaran ditengah pandemi covid-19 tetap terlaksana dan materi tetap tersampaikan kepada peserta didik sesuai dengan Surat Edaran dari pemerintah. Pendirian para guru yang menganut pembelajaran tuntas ialah bahwa faktor waktu sangat esensial untuk mengusai bahan pelajaran sepenuhnya ditengah pandemi covid-19. Dengan mengizinkan dan memberikan waktu secukupnya setiap peserta didik dapat menguasai materi yang sudah diajarkan oleh guru IPS. Peserta didik yang berbakat lebih cepat menangkap isi pelajaran. Sedangkan peserta didik yang tidak begitu tinggi bakatnya juga akan mampu menguasainya, asal mereka diberi waktu yang lebih banyak. Perlu kiranya diselidiki hingga mana yang dapat dipertinggi efisiensi belajar peserta didik ditengah pandemic covid-19.

Yang ke empat yaitu karakteristik peserta didik. Peneliti telah menyimpulkan bahwa penentuan diagnostic kesulitan pada peserta didik oleh guru Mata Pelajaran IPS ditengah pandemi covid-19 yaitu terkait alat pembelajaran berupa laptop atau smartphone, jaringan internet yang kurang stabil, kuota internet yang terbatas, penguasaan materi pada peserta didik, dan pelaksanaan penilaian pada peserta didik.

Berdasarkan hasil penelitian yang telah dilakukan, faktor kendala perencanaan pembelajaran tuntas ditengah pandemi covid-19 oleh guru mata pelajaran IPS di SMP N 1 Karangpucung, SMP Islam Karangpucung dan MTS Nurul Huda Karangpucung yaitu kurangnya kualitas SDM yaitu latarbelakang guru yang tidak relevan sehingga kesulitan dalam merencanakan pembelajaran tuntas ditengah pandemi covid-19, kesiapan guru dan peserta didik yang masing kurang dan sarana prasarana sekolah yang masih kurang memadai.

\section{PEMBAHASAN}

Faktor kendala perencanaan pembelajaran tuntas ditengah pandemi covid-19 oleh guru IPS Kecamatan Karangpucung Kabupaten Cilacap 


\section{Kualitas Sumber Daya Manusia}

Faktor kendala perencanaan pembelajaran tuntas ditengah pandemi covid-19 oleh guru mata pelajaran IPS SMP $\mathrm{N} 1$ Karangpucung, SMP Islam Karangpucung dan MTS Nurul Huda Karangpucung yaitu yang pertama kurangnya kualitas SDM latarbelakang guru yang tidak relevan. Terkait penguasaan materi, struktur, konsep dan pola pikir keilmuan, terdapat kendala dikarenakan background pendidikan yang tidak liniear dengan IPS. Di SMP Islam Karangpucung, semua guru IPS bukan .berlatarbelakang IPS melainkan berlatarbelakang Ekonomi dan IPA. Di SMP N 1 Karangpucung terdapat guru IPS yang berlatarbelakang ekonomi. Di MTS Nurul Huda Karangpucung guru IPS berlatarbelakang Pendidikan Agama Islam. Hal tersebut sangat berpengaruh terhadap kinerja guru dalam melaksanakan pembelajaran tuntas ditengah pandemi covid-19.

\section{Kesiapan guru dan peserta didik}

Yang kedua yaitu kesiapan guru dan peserta didik yang masih kurang dalam pembelajaran tuntas ditengah pandemi covid19. Kendala tersebut berkaitan dengan pengembangan kurikulum yang disesuaikan dengan kondisi sekolah dan kondisi peserta didik. Selain itu, hal tersebut berkaitan dengan teknologi yang disediakan oleh sekolah terkait dengan pelaksanaan pembelajaran tuntas ditengah pandemi covid-19. Hambatan guru dalam pemanfaatan teknologi dan komunikasi yang kurang maksimal sudah dilakukan beberapa guru dengan pembelajaran yang tidak hanya dilakukan melalui whatsapp tetapi juga menggunakan video pembelajaran diselingi dengan pemberian berupa hiburan sehingga pembelajaran tidak monoton pemberian tugastugas, dengan memberikan pembelajaran dari video pembelajaran yang dibuat oleh pendidik sehingga dalam penyampaian materi lebih berasa hidup dengan adanya video pembelajaran dari guru mapel IPS ini atau juga dengan pemberian materi dari youtube berupa video pembelajaran yang disajikan dengan animasi yang dapat menarik perhatian peserta didik. Namun untuk hal ini belum semua guru menerapkan hal yang sama sebagian masih terfokus dalam penggunaan media whatsapp.

Hal ini karena fokus guru untuk mempersiapkan kondisi peserta didik ditengah pandemi covid-19 ternyata memakan waktu yang cukup lama. Kondisi peserta didik yang tidak dapat diprediksi terkadang membuat guru kesulitan untuk menyelesaikan materi, karena kehabisan waktu untuk mempersiapkan peserta didik agar siap menerima proses pembelajaran. Pendapat (Buselic, 2012) kurangnya interaksi yang efektif, minimnya pengorganisasian merupakan salah satu yang menjadi kendala pembelajaran jarak jauh, pembelajaran jarak jauh yang efektif tentu harus didukung dengan konten yang diberikan, fasilitas koneksi internet serta perhatian dan ketersediaan yang cukup besar.

\section{Sarana prasana yang kurang memadai}

Yang ketiga yaitu sarana prasarana sekolah yang masih kurang memadai. Menurut (Attri, 2012) Terdapat beberapa masalah atau kendala yang dihadapi pada pelaksanaan pembelajaran jarak jauh ini, seperti biaya, motivasi belajar, layanan, umpan balik, kurangnya pengalaman serta kebiasaan Pembelajaran tuntas ditengah pandemic covid19 cukup berbeda dengan pembelajaran sebelum adanya covid-19, yang diperlukan dalam pembelajaran tuntas ditengah pandemi covid-19 yaitu jaringan internet yang stabil, kuota internet dan gadget atau alat untuk melakukan pembelajaran ditengah pandemi covid-19. Di tiga sekolah tersebut, kendala yang dihadapi hamper sama karena peserta didik berlatarbelakang berbeda-beda. Banyak peserta didik yang mengeluh dengan kendala yang dialami tersebut. Untuk saat ini, sekolah belum memberikan solusi terkait dengan kendala alat untuk pembelajaran ditengah pandemi covid-19. Tetapi sekolah memberikan beberapa pilihan kepada peserta didik yang tidak mempunyai alat untuk melakukan pembelajaran yaitu pembelajaran dilakukan secara guling (guru keliling), ikut belajar bersama bersama teman yang mempunyai smartphone atau dating ke sekolah dan menggunakan komputer sekolah untuk pembelajaran.

Dijelaskan (Warsito, 2007) menyatakan bahwa, ada beberapa karakteristik pendidikan jarak jauh antara lain: (1) Adanya keterpisahan pembelajaran yang mendekati unsur permanen antara tenaga pengajar dari perserta didik selama program pendidikan berlangsung, (2) Adanya keterpisahan antara seseorang perserta didik dengan perserta didik lainnya selama program pendidikan. (3) Adanya suatu institusi yang mengelolah program pendidikannya, (4) Pemanfaatan sarana komunikasi yang baik mekanis sebagai bahan belajar. (6) Penyedian sarana komunikasi dua arah sehingga perserta didik dapat mengambil inisiatif dialog dan mencari dan mengolah manfaat. 


\section{Upaya yang dilakukan oleh sekolah}

Sekolah juga memiliki upaya-upaya untuk mengatasi kendala dalam pelaksanaan pembelajaran tuntas ditengah pandemi covid19.

Upaya dapat dikatakan sebagaisuatu usaha, akal, ikhtiar untuk mencapai suatu maksud, memecahkan persoalan dengan mencari jalan keluar. Guru atau pendidik adalah orang yang mengajar dan membari pengajaran karena hak dan kewajibannya bertanggung jawab kepada peserta didik (Ramayulis, 2002). Baik itu upaya dari guru IPS itu sendiri dan upaya dari kepala sekolah. upaya yang dapat dilakukan untuk mengatasi kendala pembelajaran tuntas ditengah pandemi covid-19 yaitu Menciptakan kesempatan belajar yang lebih baik lagi agar peserta didik lebih aktif, percaya diri, memperhatikan kondisi peserta didik, mempunyai motivasi untuk belajar, memperbaiki komunikasi dengan peserta didik, berkoordinasi dengan orangtua peserta didik, membuat pembelajaran daring dengan sekreatif mungkin agar peserta didik lebih semangat belajar, pengembangan dalam metode pembelajaran dan pelaksanaan webinar atau diklat untuk guru mata pelajaran IPS.

\section{Upaya yang dilakukan MGMP IPS Kabupaten Cilacap}

Selain upaya dari sekolah, MGMP IPS

Kabupaten Cilacap berupaya aktif lagi dalam mendorong meningkatkan kualitas guru IPS misalnya MGMP memberikan batasan materi sehingga guru terfokus pada materi tersebut dan kita tidak ada kisi kisi soal. Jadi kita ingin berperan lebih jauh tetapi pada masa pandemi ini sangat sulit karena komunikasi sangat terkendala. Dalam proses belajar mengajar, aktivitas peserta didik sangat diharapkan tidak hanya aspek fisik, tetapi juga aspek mental. Peserta didik bertanya, menyampaikan pendapat, mengerjakan tugas, berdiskusi, menulis, membaca, dan perhatikan poin-poin penting penjelasan guru, sejumlah kegiatan peserta didik yang aktif secara mental dan fisik. Inilah aktivitas para peserta didik lebih dari aktivitas guru. Guru hanya sebagai pemandu dan sebagai fasilitator kegiatan belajar peserta didik pada saat pembelajaran. Guru terkadang melakukan tindakan untuk menenangkan suasana pembelajaran sehingga terjalin interaksi yang kondusif antara guru dan peserta didik. Satu dari upaya untuk menarik perhatian peserta didik adalah dengan memanfaatkan media yang merangsang peserta didik untuk berpikir, cara lain adalah menghubungkan apa yang akan dijelaskan dengan ilmu yang telah diperoleh dimiliki oleh peserta didik.

Salah satu upaya membantu peserta didik agar mudah menerima dan memahami materi pelajaran yang diberikan ditengah pandemic covid-19 adalah dengan cara pengulangan kunci secara berulang, jadi itu membantu peserta didik menyerap materi pelajaran dengan mudah. Pemahaman semakin banyak lama jelas di otak peserta didik.

\section{SIMPULAN}

Berdasarkan penelitian mengenai "Faktor kendala perencanaan pembelajaran tuntas ditengah pandemi covid-19 oleh guru mata pelajaran IPS Kecamatan Karangpucung Kabupaten Cilacap", maka dapat ditarik kesimpulan bahwa penerapan pembelajaran tuntas di kecamatan Karangpucung kabupaten Cilacap belum maksimal. Faktor kendala yang dialami dalam perencanaan pembelajaran tuntas yaitu meliputi yaitu latarbelakang guru yang tidak relevan sehingga kesulitan dalam merencanakan pembelajaran tuntas ditengah pandemi covid-19, kesiapan guru dan peserta didik yang masing kurang dan sarana prasarana sekolah yang masih kurang memadai. Berdasarkan hasil penelitian yang telah dilakukan, sekolah juga memiliki upaya-upaya untuk mengatasi kendala dalam pelaksanaan pembelajaran tuntas ditengah pandemi covid19. Baik itu upaya dari guru IPS itu sendiri dan upaya dari kepala sekolah. upaya yang dapat dilakukan untuk mengatasi kendala pembelajaran tuntas ditengah pandemi covid-19 yaitu Menciptakan kesempatan belajar yang lebih baik lagi agar peserta didik lebih aktif, percaya diri, memperhatikan kondisi peserta didik, mempunyai motivasi untuk belajar, memperbaiki komunikasi dengan peserta didik, berkoordinasi dengan orangtua peserta didik, membuat pembelajaran daring dengan sekreatif mungkin agar peserta didik lebih semangat belajar, pengembangan dalam metode pembelajaran dan pelaksanaan webinar atau diklat untuk guru mata pelajaran IPS.

Berdasarkan analisis pemahaman yang diperoleh dan beberapa faktor yang menjadi kendala, forum MGMP IPS Kabupaten Cilacap melakukan kegiatan- kegiatan yang dapat membantu guru untuk meningkatkan kualitas mengajarnya. Kegiatan yang dilakukan MGMP sebelum pandemi merupakan MGMP aktif dan diakui oleh MGMP yang lain dan sering diberi kepercayaan oleh dinas utuk melakukan 
kegiatan. Melakukan workshop penulisan soal kaitannya terkendala dengan KKM. Pada masa pandemi ini yang sudah dilakukan MGMP IPS yaitu meminta kepada bapak ibu guru untuk menyusun modul daring maupun luring. Upaya yang dilakukan MGMP IPS yaitu MGMP mencoba berperan lebih aktif lagi dalam mendorong meningkatkan kualitas guru IPS misalnya MGMP memberikan batasan materi sehingga guru terfokus pada materi tersebut dan kita tidak ada kisi kisi soal. Jadi kita ingin berperan lebih jauh tetapi pada masa pandemi ini sangat sulit karena komunikasi sangat terkendala.

\section{DAFTAR PUSTAKA}

Amri, Sofan. Iif Khoiru Ahmadi. 2010. Proses Pembelajaran Kreatif dan Inovatif Dalam Kelas: Metode, Landasan Teoritis-Praktis dan Penerapannya. Jakarta: PT. Prestasi Pustakaraya.

Attri, A. K. 2012. Distance Education: Problems And Solution International. Journal of Behavioral Social And Movement Sciences. 1(4), 42-58

Basuki. (2011). Belajar Tuntas (Mastery Learning). Diakses di http://sumsel.kemenag.go.id pada 17 Juli 2021

Buselic, M. 2012. Distance Learning-Concepts and contribution. Oeconomica Jadertina, I, 23-24.
Dimyati dan Mudjiono. 2006. Belajar dan Pembelajaran. Jakarta: PT Rineke Cipta.

Kemendikbud .(2016). Permendikbud Nomor 22 Tahun 2016 Tentang Standar Proses Pendidikan Dan Menengah. Jakarta: Kemendikbud.

Moleong, L.J. (2011). Metodologi Penelitian Kualitatif Edisi Revisi. Bandung: PT. Remaja Rosdakarya.

Permendiknas No. 41 Tahun 2007 tentang Standar Proses Untuk Satuan Pendidikan Dasar dan Menengah.

Ramayulis. 2002. Ilmu Pendiidikan Islam. Jakarta: Kalam Mulia

Rizqon Halal Syah Aji. "Dampak Covid-19 pada Pendidikan di Indonesia: Sekolah, Keterampilan, dan Proses Pembelajaran". SALAM; Jurnal Sosial \& Budaya Syari. Vol. 7 No. 5 (2020):1-10.

Sapriya. 2011. Pendidikan IPS: Konsep dan Pembelajaran. Bandung: PT Remaja Rosdakarya.

Sugiyono. 2017. Metode Penelitian Kuantitatif, Kualitatifdan R\&D. Bandung: Alfabeta.

UU No 20 Tahun 2003 Tentang Sistem Pendidikan Nasional

Warsito, Peran TIK dalam Penyelenggaraan PJJ. Jurnal Teknodik April 2007. No. 20: 941. Jakarta: Pustekkom depdiknas

Yamin, Martinis. 2008. Paradigma Pendidikan Konstruktivistik. Jakarta: Gaung Persada Press 